\title{
CISD1 Gene
}

National Cancer Institute

\section{Source}

National Cancer Institute. CISD1 Gene. NCI Thesaurus. Code C113133.

This gene is involved in both iron-sulfur cluster binding and electron transport. 